\title{
Urban Socio-Economic Variables and Intra-Urban Trips in Ogun State, Nigeria
}

\author{
Solanke Muse Olayiwola
}

Received: 0402 2014 / Accepted:19 02 14/ Published online: 30062014

(๑) 2014 Faculty of Geography UGM and The Indonesian Geographers Association

\begin{abstract}
This study examines the relative influence of socio-economic variables of urban centers on intra-city trip generation. Data were collected on sixteen socio-economic variables and household trip generation in fourteen urban centers of the state. The nature and degree of relationships between socio-economic variables and trips generated were established through simple bivariate correlation technique. Multiple regression analysis was used to explain variables that predict trips generated. The principal component analysis was used to resolve observed collinearity problem in regression analysis. There is a strong significant positive correlation between trip generated and 13 out of sixteen socio-economic variables. The principal component analysis on the socio-economic variables produced two components: social and commercial component and industrial development component. The two components explain $58.68 \%$ of variation in intra-urban trips generated $(\mathrm{F}=7.830, \mathrm{P} \leq 0.50),(\mathrm{F}=13.982, \mathrm{P} \leq 0.50)$. The industrial development component does not provide significant explanation. The study emphasizes the need for proper planning and effective monitoring of developing of socio-economic variables in cities because of their critical influence on trip generation.
\end{abstract}

Keywords: Trip generation, urban centers, Nigeria, intra-urban travels, Ogun State.

\begin{abstract}
Abstrak Penelitian ini menguji pengaruh relatif variabel sosio-ekonomi dari pusat-pusat perkotaan terhadap munculnya perjalanan intra-perkotaan. Data yang digunakan berupa enam belas variabel sosio-ekonomi dan data perjalanan intraperkotaan oleh rumah tangga di empat belas pusat-pusat perkotaan. Sifat dan derajat hubungan antara variabel sosio-ekonomi dan jarak perjalanan yang dihasilkan dianalisis melalui teknik korelasi bivariat sederhana. Analisis regresi berganda digunakan untuk menjelaskan variabel prediksi perjalanan yang dihasilkan. Komponen utama analisis yang digunakan untuk analisis kolinearitas adalah analisis regresi.Terdapat korelasi positif yang signifikan yang kuat antara perjalanan yang dihasilkan dan tiga belas dari enam belas variabel sosio-ekonomi. Analisis variabel sosio-ekonomi menghasilkan dua komponen : komponen sosial-komersial serta komponen perkembangan industri. Dua komponen ini menjelaskan 58,68 $\%$ variasi dalam perjalanan intra-perkotaan yang dihasilkan $(F=7.830, P \leq 0.50),(F=13,982, P \leq 0,50)$. Komponen perkembangan industri tidak memberikan hasil yang signifikan. Studi ini menekankan perlunya perencanaan yang tepat dan pengawasan yang efektif untuk memantau perkembangan sosio-ekonomi di kota-kota karena pengaruh kritis mereka pada perjalanan yang dihasilkan.
\end{abstract}

Kata kunci: Penentu perjalanan, pusat perkotaan, Nigeria, perjalanan intra-perkotaan, Kawasan Ogun.

\section{Introduction}

Trip generation, consequent upon human travel is inevitable. It takes place as a result of urge or desire to satisfy felt needs arising from the separation of land uses. In urban centers worldwide, human travels take place when residents carry out their different activities in different places either by necessity or by choice. In some distant past, especially before the advent of modern transportation, the morphology of cities where dependent upon the mode of movement. In cities where there were canals, the structure was linear as water allowed easy interaction between one place and the other. In cities where this did not exist, the structure was es sentially concentric as city plans were done in a way to minimize transport. Such cities had high densities of housing and population. Houses were multipurpose in

\section{S. M. Olayiwola}

Department Of Geography And Regional Planning, Olabisionabanjo University

Email: solankeolayiwola@yahoo.com nature as they provided residences and workshops. Because of lack of mechanized transport, the early towns were small in size, intra-city mobility was low, restricted to short trek able distances and carrying of goods by head portage [Solanke, 2005; Oyesiku, 2010].

The city of today is no doubt very complex; covers large expanse of land and acco-mmodates varied activities. One of the outcomes of this is the separation of urban land use components. Today, long distances are involved in intraurban movements; the mode of movement which was characterized by trekking in early period had been replaced by mechanical locomotion. It then becomes necessary for interaction to increasewithin urban centers. Hence, Socio-economic variables of urban centers constitute considerable potentials of trip generation. Studies [Ayeni, 1974; Adeniyi, 1981; Ogunsanya, 2002; Solanke, 2005; Raji, 2013] have shown that in general, people tend to travel in order to obtain access to a variety of other peoples services and facilities 
that are not available at the origins of their journeys. In fact trip generation in urban centers has been logically described as a function of complex interaction of socioeconomic factors relating to both the residents and urban centers [Oyesiku, 1990; Hanson and Schwab, 1995; Solanke, 2005].

The work of Adeniyi $[1985,1987]$ revealed that pattern of urban movement is influenced by the size and density of settlement, topography, length of journey, income and household characteristics. It is also emphasized that demand for transport and travel intensity tend to increase sharply with the size of a city especially when the center or major areas of activity increase correspondingly in terms of both area and employment. Also, Hanson and Schwab [1995] noted that trip characterristics vary with the characteristics of traveller and with the nature of the urban environment and transportation system. Among the aspects of the urban environment that help to shape travel pattern according to Hanson and Schwab [1995] include the location and quality of different activity sites or potential destinations such as employment places, retail outlets, parks, banks, medical facilities and schools. In other words, the socioeconomic variables of urban centers. While the works of Adeniyi [1985] and Hanson and Schwab [1995] provide some useful guides into the study of urban trip generation pattern, they did not demonstrate in empirical terms the influence of each of these variables on trip generation in urban centers; a shortcoming that necessitates further empirical study on urban trip generation.

The work of Barber [1995] emphasized that not all the regularities that characterize the pattern of travel flows are exhibited to the same extent in every North American city. He noticed a tremendous diversity in the size, function and structure of North American Cities. The four characteristics of a city that have implication on the pattern of urban travel flows according to this author [Barber, 1995] are:

1. The absolute size of the city, expressed either in terms of population and or built-up areas

2. The principal function of the city, for examplemanufacturing, tourism and administration.

3. The particular geographical setting

4. The proportion of the growth of the city that occurred in each of the major transportation technology eras.

The idea above suggests there would be significant differences in the trip generation between one city and the other, especially between an older city of a region and rapidly growing city due to variation in the level of socio-economic variables among urban centers.

However, in spite of the numerous evidences supporting the contribution of socio-eco-nomic factors of urban centres to trip gene-ration, an explicit picture of the relationship between the two (trip generation and socio-economic variables) still need to be established. In other words, the potentials/relative importance or otherwise of each of development indicators in a city is yet to receive desired attention in urban transportstudies. This study therefore focuses on socio-economic variable of urban centers in relation to intra-city trip generation. This is an attempt to answer a pressing question usually faced by policy makers when considering changes in urban trip generation especially along what perspective of socio-economic variables must an urban center develops to cause a significant change in urban travel?

The study area, Ogun State is one of the fast developing states in Nigeria. It is in the South western part of the country within latitudes $60 \mathrm{~N}$ and $80 \mathrm{~N}$ and longitudes $30 \mathrm{E}$ and $50 \mathrm{E}$. The state is bounded on the west by the Republic of Benin and on the east by Ondo State. To the north is Oyo State, while Lagos State and the Atlantic Ocean are to the south (Figure 1). The state covers about 16,762 square kilometer which is approximately 1.81 percent of $\mathrm{Ni}$ geria's land mass of about 923,768 square kilometers.

The geology of the state comprises the sedimentary and basement complex rocks. According to Akanni [2000] about $1,200-\mathrm{km}^{2}$ of the state is of sedimentary formation while about $400 \mathrm{~km}^{2}$ is of basement complex rocks of pre-Cambrian formation. The relief of the state, like other parts of the country is more or less coinciding with the major rocks types.

There are two main relief regions: first, the creeks and lagoons forming a small section in the south eastern part of the state, the altitude of which ranges from 0 to 40 meters above the sea level. Second, the undulating coastal plain and the low lands with the elevation increasing northwards from about 30 to 250 meters above sea level. The plain is broken by sand stone cresta especially towards the western part of the state. There are pockets of rock Outcrops dotting the landscape especially around state capital (Abeokuta). The whole state is drained by flowing coastal rivers such as Ogun, Yewa, and Shasha from Oyo state through the thickly vegetated western part of the state. Numerous small rivers and streams are at the south eastern parts flowing perennially through the swampy terrain.

The state is within the tropical humid climatic zone of Nigeria which is generally characterized, by high rainfall and high relative humidity. This is attributable to the prevalence of moisture laden tropical maritime air mass over the state for about nine months in a year. The mean relative humidity varies from $66.2 \%$ in January to $88.4 \%$ in July [Akanni, 2000].

The rainfall shows a double maximadistri-bution reaching the peak during the months of June and September.The average monthly rainfall for the state ranges between $7.1 \mathrm{~mm}$ in the month of January to $208.27 \mathrm{~mm}$ in the month of June. The mean annual temperatureis $26^{\circ} \mathrm{C}$; although with some variations over time. The mean diurnal minimum temperature varies from $21.8^{\circ} \mathrm{C}$ in December to $24.34^{\circ} \mathrm{C}$ in April while the mean diurnal maximum temperature varies from $33.92^{\circ} \mathrm{C}$ to $37.1^{\circ} \mathrm{C}$ at the onset of the wet season (March and April) [Akanni, 2000]. 
On the basis of climatic features, the state is characterized by two distinct weather seasons: the wet and dry. The wet season marked by lower mean temperature, higher total rainfall and higher relative humidity is usually experienced between the months of February and October. However, little dry season is sometimes experienced in August, a phenomenon characterized by drastic reduction in the frequency and intensity of rainfall and referred to as 'August break'. The dry season sets in by November and persists till the end of January. It is usually accomplished by harmattan cold, brought by the prevailing north-west winds.

In terms of vegetation, the state can be divided into three distinctive zones. Where the state shares a boundary with the Atlantic Ocean, the vegetation is of a swampy type with mangroves and other edaphic trees. There is also rainforest vegetation in some section of the state while the state capital (Abeokuta) and some areas are characterized by derived forest vegetation, having been altered by human activities.

In the pre-colonial era, the economy of the state, like those of most other traditional Nigerian towns was characterized by farming, craft production, trade and town administration [Oyesiku, 1990; Ademiluyi 1996].

The establishment of colonial rules in the state brought new forms of economic activities which are characteristics of western economy, and there have also beensome modifications to the traditional system of production. Thus, several identifiable modern economic activities including banks, insurance, houses, modern and traditional markets, petrol stations, motor companies, commercial enterprises, light and heavy industrial organizations are now found in different urban centers in varying degrees.Some settlements, especially the capital (Abeokuta) benefited immensely from their early contactwith the European population (the missionaries) who helped in the development of such areas by establishing mission houses, schools, churches, dispensaries and hospitals.

Agriculture the mainstay of the economy provides the major single occupation for the people of the state especially those in the rural areas. Arable crops like maize, yam, cassava, rice, cocoyam, groundnut, melon, banana plantain, oranges, pineapple, sugar-cane and kolanuts are produced in the state. The major export crops produced are cocoa, coffee, rubber and palm kernel. In the Riverine areas, people engage in extensive fish farming, lumbering activities also thrive because the state is endowed with appreciable forest resources. This perhaps accounts for the high number of sawmills in the state.

Another major economic activity in the state is extensive trading and light commercial merchandising. The people are engaged in buying and selling of all types of goods ranging from local household utensils in food, beverage and manufactured goods. The industrial sector constitutes another economic activity. Among the major industrial types in the state are: food, beverages and tobacco, textile, weaving apparel and products, fabricat- ed metalproducts, wood and wood products, chemical products, pulp, paper products, printing and publishing, non-metallic minerals, motor vehicles and miscellaneous assemblies, domestic/industrial plastic and rubber products and electrical and electronics [Odugbemi, 1993]. The potentials of the state for industrial development are as a result of her natural, agricultural and forestry resources and proximity to Lagos and Ibadan [Odugbemi, 1993; Odugbemi and Solanke, 1997].

People in the state also engaged in paid employment of the local, state and federal government agencies, others engage in business activities which are dominated by distributive trade, personal services, transportation, finance and insurance services.To complement the socio-economic development of the state are education, health, telecommunication, postal and insurance institutions and other socio-economic services and infrastructures that exist in many towns. For instance, the state has about 1,424 public primary schools, 474 public, secondary schools, 7 government technical colleges, 1,120 registered private nursery and primary schools, 257 registered private secondary schools, 2 colleges of education, 4 polytechnics, 3 public universities and 8 private universities.

Also there are 88 hospitals/clinics (public and private) 210 maternity centers, 202 dispensaries, 16 comprehensive/primary health centers, 4 dental centers and 1 university teaching hospital. Notable tourist attractions in the state are Olumo Rock at Abeokuta, BirikisuSungbo Shrine at Oke-Eri, Ebute-Oni Beach, Oronna Shrine and the Celestial city at Imeko.

\section{The Methods}

Both secondary and primary data were used in this study. The secondary data are the socioonomic variable/development indicators of the urban centers. Various government publications on Ogun State such as the state's statistical year book and abstract of statistics, Local Government Digests, technical reports, academic journals and other periodic publications of Ogun State ministry of finance and economic planning provided the bulk of secondary information for this study. The federal office of statistics and national population commission also provided some information on the population figures of the cities.

In the literature, little agreement exists on the range of indicators to be included in the measurement of development level of an area unit. A review of research works on regional development in the developing societies for instance reflects the concatenation of socio and eco nomic variables in various forms [Onyemelukwe, 1981; Abumere, 1987; Ghaffar, 1987; Ademiluyi, 1996] among others and thus, serves as antecedents to this study.

In all sixteen socio-economic variables considered paramount and relevant as potentials of urban trip generation were collected. They are: (1) rate ablehereditaments, (2) population, (3) telephone lines, (4) nursery/primary schools, (5) secondary school (6) 
tertiary institution, (7) public health center, (8) private health centers, (9) traditional market, (10) modern market, (11) industrial establishment, (12) post offices (13) postal agencies, (14) stadia/sport centers, (15) hotels, and (16) tourist/recreational facilities.

These variables and services were chosen because they were measureable, relatively available and they have been recognized as measures of urban socioeconomic growth [Oyebanji, 1981; Ademiluyi, 1996].

The primary source of data is questionnaire survey for urban residents on household basis. Following the works of Ogunjumo [1986], Oyesiku [1990], Dimitriou [1995] and Solanke [2005], household is a well-known key decision-making unit for the general movement pattern and constitutes the major point of origin of urban travel. An urban center is defined as the settlement with a total population of 20,000 people or more in conformity with United Nations and the definition of urban centers in the Nigeria national population census of 1963, 1991 and 2006. On the basis of this definition, there are 22 urban centers in the state. 14 of these in different categories (such as large, medium and small) in terms of population sizes were randomly selected. They are: Abeokuta (the state capital), Ijebu-Ode, Sagamu,Ilaro, Ago-Iwoye, Ota, Ijebu-Igbo, Ayetoro, Ifo, Iperu, Ado-Odo, Idi-Iroko, Owode-yewa and Alagbado.

A household survey was conducted in each of these selected urban centers to generate data on urban travels. Each urban center was divided into residential quarters along the demarcation of the town into residential neighborhoods by the Town Planning Authorities (TPA). In each of the neighborhoods, random selection of streets and systematic sampling of the housing unit were made. The size of the household interviewed was based on the estimate for each urban center. There are about 425,789 households in all the selected urban centers out of which 2,385 were sampled in proportion to the number of household in each city (Table 1), 2,100 fully completed copies of the questionnaire were used in this study.

The questionnaire dealt among others with frequency of trip generation in each urban centeron household basis. Frequency of trip in this study is de- fined as the mean trip generated by individual households in urban centers for a period of time (e.g. a week). This is estimated by dividing the total trips generated by households for various purposes within a designated period by the number of households sampled in the city.

The nature and degree of relationships between socio-economic variables of urban centers and household frequency of trip were established through simple bivariate correlation technique.

Multiple regression analysis was used to explain the socio-economic variables that predict intra-urban travels in the state. The stepwise version of the model was used to determine the most important variables explaining the observed pattern of travel.

The principal components analysis was used to resolve some of the problems met in order to satisfy the assumption of the multiple regression analysis as well as for data parsimony.

\section{Result and Discussion}

Table 2 shows that the mean trip generated by the urban centers of Ogun State, Nigeria and each of the socio-economic variables are positively correlated. This indicates a positive interaction pattern between trip generated and socio-economic variables and thus, reinforces the assertion earlier made in this study that, socio-economic variables of urbancenters are potentials for spatial interaction within cities.

Therelationship between meatri generated and some variables is very strong while with others, it is very weak. There is a strong positive correlation co-efficient of not less than 0.70 between mean trips generated and the following variables: hotels, primary schools, population, private health centers, secondary schools, stadium/sport centers, telephone lines and traditional markets. Fairly high positive correlations of between 0.5 and 0.6 exist between mean trips generated and each of the following variables: postal agencies, public health centers, ratable hereditament, tertiary institutions, tourist centers and post offices. Furthermore, a very weak positive correlation exists between mean trips generated and industrial estab-

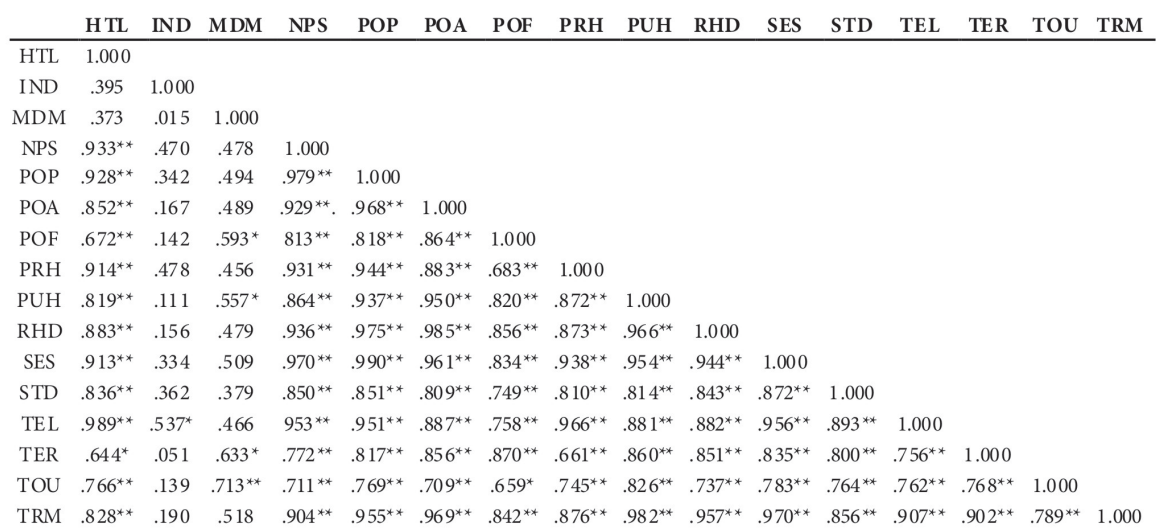

Picture 1. Ogun state and its neighbours 
Table 1. Urban centers in Ogun State, estimated number of households and sample sizes

\begin{tabular}{lrrr}
\hline S/NO & Urban Center & Estimated number of household & Household sample size \\
\hline 1. & Abeokuta & 141,455 & 792 \\
2. & Ijebu-ode & 49,621 & 278 \\
3. & Sagamu & 51,136 & 286 \\
4. & Ilaro & 15,609 & 87 \\
5. & Ago-iwoye & 11,882 & 67 \\
6. & Ota & 41,439 & 232 \\
7. & Ijebu-ogbo & 26,036 & 146 \\
8. & Ayetoro & 12,095 & 68 \\
9. & Ifo & 21,033 & 118 \\
10. & Iperu & 9,277 & 52 \\
11. & Ado-odo & 9,221 & 52 \\
12. & Idi-iroko & 6,981 & 39 \\
13. & Owode & 15,780 & 88 \\
14. & Alagbado & 14,224 & 80 \\
& Total & 425,789 & 2,385 \\
\hline
\end{tabular}

lishments (0.396) as well as modern markets (0.279).

The strong to fairly high positive correlations between mean trip generated and all variables other than industrial establishments and modern markets is noteworthy. It shows that with high concentration of such variables as hotel, primary schools, popula tion, postal agencies, ratable hereditament, second ary schools, stadia/sports centers, telephone facilities, tertiary institutions, tourist centers and traditional markets, the urban centers tend to generate more intra-city trips. This finding agrees with earlier studies such as those by Filani [1972] in United States of America and Lee [1972] in Taiwan where positive relationship was established between trips generated and socio-economic variables in general.

Generally, regression model performs two basic functions namely: Predictive and explanatory functions [Blalock, 1963; Oyesiku, 1990; Ayeni, 1994; Barber, 1995; Okoko, 2000; Solanke, 2005; Raji 2013]. Emphasis on the predictive equations is on obtaining the co-efficient of determination $\left(\mathrm{R}^{2}\right)$ with the aim of maximizing the variance in the dependent variable that are accounted for by a given set of independent variables. In other words, in this study the predictive function of the model strives to present the combine effect of the independent variables (the urban socio-economic variables) on the dependent variable (the trip generated).

The explanatory function of the model shows the separate influence of the independent variables in order to establish the importance of the relationship of each of the independent variables on the dependent variable.

In formulating the explanatory model, through multiple regression, the traditional multi-collinearity problems amongst inter correlated independent variables must first be eliminated or reduced to be bar- est minimum. There are various methods to test for multi-collinearity in a data. These include the Eigen value method and that which entails examination of pairwise correlations among independent variables. There is no general consensus as regards the level of collinearity which adversely affects the estimates of regression parameters. Hauser [1974] noted that a pairwise correlation between explanatory variables in excess of 0.80 depicts serious collinearity and this cut off point has been widely used in research [Oyesiku, 1990; Ojo, 1990; Solanke, 2005].

An examination of the zero-order correlation matrix of explanatory variables (socio-economic variables) (Table 3 ) shows that a very strong positive correlation in excess of 0.80 exists between population and each of the following variables: hotels (0.928), primary schools $(0.979)$, postal agencies $(0.968)$, private health facilities (0.944), public health facilities (0.937), ratable hereditaments (0.975), secondary schools (0.990), telephone facilities (0.951), traditional market $(0.955)$, post offices $(0.818)$, sport facilities $(0.851)$ and tertiary institutions (0.817). Also, strong correlation in excess of 0.80 exists between hotel and each of the following: primary schools (0.933), private health centers (0.914), secondary schools (0.93), postal agencies $(0.852)$ sport facilities $(0.836)$, telephone facilities (0.898) and traditional markets (0.828). All these are indications of seriouscollinearrity problems among the variables. In order to overcome these problems, the principal component analysis is employed. The principal component analysis technique is also relevant in a situation where the number of explanatory variables that are theoretically relevant in a regressionmodel is very large relative to or more than the cases (observations) [Oyesiku, 1990; Okoko, 2000]. 
Table 2. Relationship between mean trip generated and socio-economic variables of urban centers

\begin{tabular}{lr}
\hline Socio-economic variables & Relationship with trip generated \\
\hline Hotel & $0.724^{* *}$ \\
Industry & 0.396 \\
Modern market & 0.279 \\
Primary school & $0.734^{* *}$ \\
Population & $0.737^{* *}$ \\
Postal agency & $0.643^{*}$ \\
Post offices & 0.531 \\
Private health centers & $0.761^{* *}$ \\
Public health centers & $0.688^{* *}$ \\
Reteablehereditament & $0.679^{* *}$ \\
Secondary school & $0.772^{* *}$ \\
Sport centers & $0.700^{* *}$ \\
Telephone lines & $0.744^{* *}$ \\
Tertiary institution & $0.569^{*}$ \\
Tourism & $0.628^{*}$ \\
Traditional markets & $0.703^{* *}$ \\
$\star *$ Correlation is significant at the level 0.01 level &
\end{tabular}

This is the case of the data being used for the regression analysis in this study. There are fourteen urban centers (cases) as against sixteen explanatory variables. Principal Component Analysis structures a set of data into truly independent factors and reduces the set of interrelated variables into a smaller group of uncorrelated orthogonal factors which together explain most variations in the original set of data. Orthogonal transformation of a set of variables $\left(\mathrm{X}_{1}, \mathrm{X}_{2}, \mathrm{X}_{3} \ldots \mathrm{Xn}\right)$ into a new set of uncorrelated variables $\left(\mathrm{Y}_{1}, \mathrm{Y}_{2}, \mathrm{Y}_{3} \ldots \mathrm{Yn}\right)$ is the main essence of principal components analysis.

A major problem in the application of this technique is how to determine the number of components that the researcher needs to represent the data. The Kaiser's [1960] eigen-value one criterion and Cattel's [1966] scree test are recognized approaches as solutions to such a problem. The eigen value greater than one criterion has been given wider applications in research [Blalock, 1963; Lee, 1972; Oyesiku, 1990; Solanke, 2005; Raji, 2013] and therefore is used in this study. The results of the principal component analysis on sixteen socio-economic variables of the urban centers are shown in tables 4 and 5 . Table 4 shows that there are two components that explain the underlying similarities of the sixteen variables. Table 5 further reveals that these two principal components accounted for about $88 \%$ of the variation in the original data.

On the basis of the high percentage of the total variance explained by these components, they can be described to have adequately represented the original data. The first component has Eigenvalues of 12.620 and accounted for about $79 \%$ of the variance in the origi- nal data. All these variables, except, industrial establishments loaded highly on this component. All these variables also have positive signs. Component I is named social and commercial factor. The second component has Eigen value of 1.436. Only one variable (industrial establishments) loaded highly on this component and accounted for about $9 \%$ of the variance in the original data. Component II is therefore named industrial development factor. Table 6 shows the pattern of the scores of the two components on the urban centers. The pattern reveals that the three highest urban centers in term of population (Abeokuta, Ijebu-ode and Sagamu) have the highest scores on the social/commercial component. Also, Otawith the highest proportion of urban industrial establishments [Solanke 2005] has the highest score on industrial development component.

The regression model is now applied to relate the two derived independent factors to the trip generated (dependent variable). The result is presented in table 7 . The two components jointly explain 58.68 of the variation in the average intra-city trips generated in the study area. With $F$ ratio of 7.830 , this result is significant at 95\% confidence level. The signs of the co-efficient of the two components show that they are both positively related to the mean trip generated. This shows that the higher the level of these facilities, the higher the trip generated by the urban centers in the study area.

Of the two components the social/commercial component alone explains $53.80 \%$ of the total variation in the mean trip generated. This is also significant at $95 \%$ confidence level. The in- 


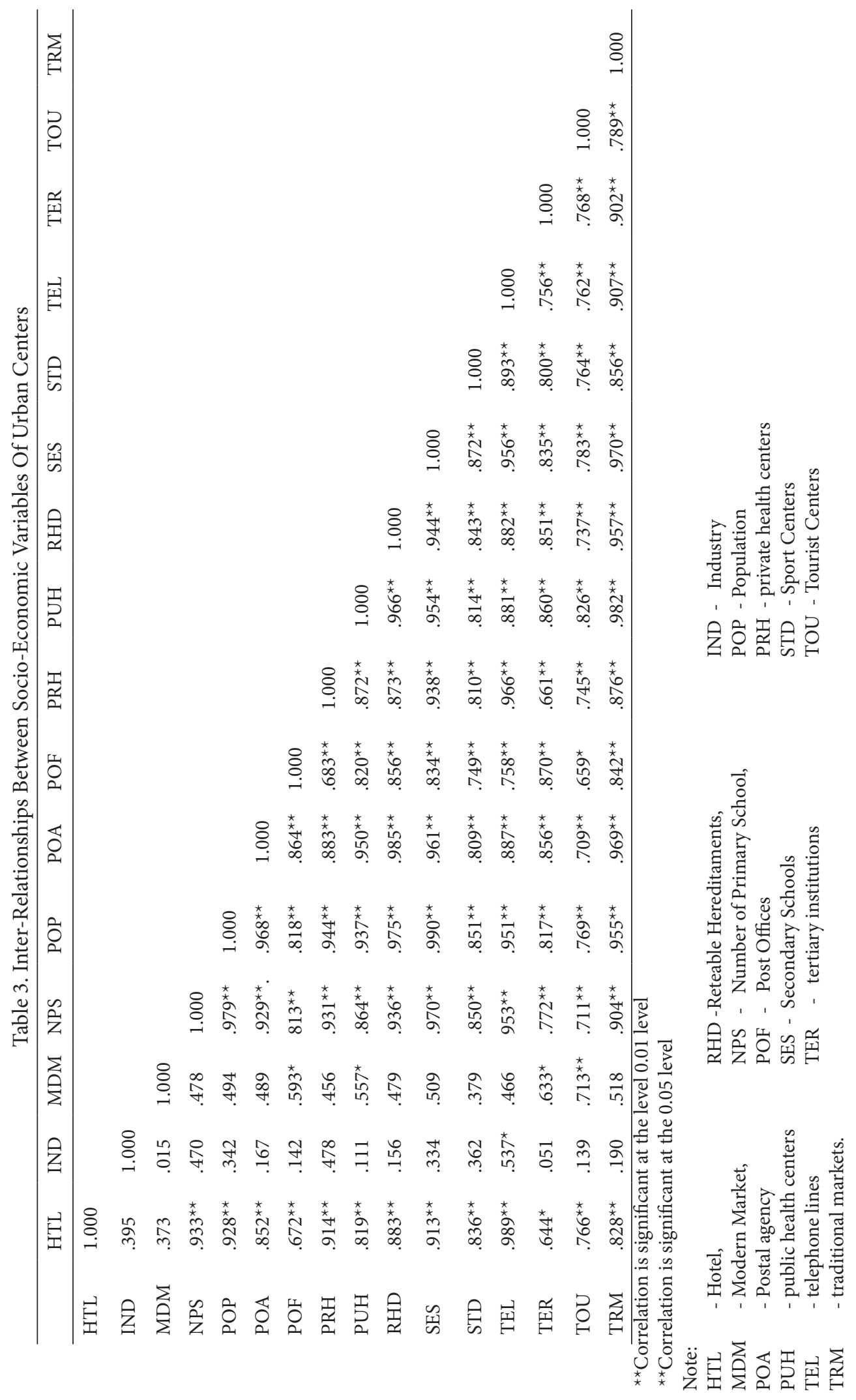


Table 4. Rotated Component Matrix of the Sixteen Socio-Economic Variables of the Urban Centers

\begin{tabular}{llrr}
\hline No & Socio-economic variable & Principal Components & I \\
\cline { 3 - 4 } & & $0.908^{*}$ & II \\
\hline 1 & Hotel & 0.315 & 0.230 \\
2 & Industry & $0.570^{*}$ & 0.844 \\
3 & Modern market & $0.964^{*}$ & -0.468 \\
4 & Primary schools & $0.986^{*}$ & 0.194 \\
5 & Population & $0.962^{*}$ & 0.07681 \\
6 & Postal agency & $0.861^{*}$ & -0.084 \\
7 & Post office & $0.930^{*}$ & -0.229 \\
8 & Primary health & $0.955^{*}$ & 0.251 \\
9 & Public health & $0.86^{*}$ & -0.171 \\
10 & Reteable hereditament & $0.991^{*}$ & -0.081 \\
11 & Secondary school & $0.895^{*}$ & 0.05325 \\
12 & Stadia & $0.957^{*}$ & 0.114 \\
13 & Telephone & $0.871^{*}$ & 0.249 \\
14 & Tertiary institution & $0.831^{*}$ & -0.341 \\
15 & Tourist centers & $0.972^{*}$ & -0.241 \\
16 & Traditional market & & -0.104 \\
\hline Socio-economic variables that loaded highly on the components
\end{tabular}

${ }^{\star}$ Socio-economic variables that loaded highly on the components.

Table 5. Eigen-values and the total variance percentage explained by each component

\begin{tabular}{lrrr}
\hline Principal component & Eigen value & \% Total Variance & Cumulative variance \\
\hline I & 12.620 & 78.874 & 78.874 \\
II & 1.436 & 8.978 & 87.852 \\
\hline
\end{tabular}

Table 6. Component scores on the socio-economic development variables of the urban centers in Ogun State

\begin{tabular}{lrr}
\hline Town & Social commercial component & Industrial development components \\
\hline Aboukuta & 3.10430 & -0.53242 \\
Ijebu-ode & 0.79076 & -0.31592 \\
Sagamu & 0.46930 & 1.01245 \\
Ilaro & -0.09202 & -1.42215 \\
Ago-iwoye & -0.36552 & -0.43823 \\
Ota & 0.17498 & 2.98284 \\
Ijebu-igbo & -0.16872 & -0.06107 \\
Ayetoro & -0.40816 & -0.05996 \\
Ifo & -32741 & -0.58099 \\
Iperu & -0.51795 & 0.07354 \\
Ado-ode & -0.64087 & -0.24590 \\
Idi-iroko & -0.69515 & -0.06980 \\
Owode & -0.71053 & -0.11871 \\
Alagbado & -0.61300 & --0.22368 \\
\hline
\end{tabular}

Table 7. Summary of the regressionresult between the trip generated and two socio-economic components

\begin{tabular}{lrrrrrrr}
\hline $\begin{array}{l}\text { Socio-economic com- } \\
\text { ponent }\end{array}$ & B coeff & $\begin{array}{r}\text { Standard } \\
\text { error }\end{array}$ & Multiple R & $\begin{array}{r}\text { Level of } \\
\text { expl. \% }\end{array}$ & $\begin{array}{r}\text { Cumulative } \\
\text { level of expl. \% }\end{array}$ & F value & T value \\
\hline Social/commercial & 4.755 & 1.272 & 0.734 & 53.80 & 53.80 & $13.982^{*}$ & $3.739^{*}$ \\
Industrial development & 1.439 & 1.255 & 0.766 & 4.88 & 58.68 & $7.830^{*}$ & 1.146 \\
\hline
\end{tabular}

* Significant at 95\% confidence level. 
dustrial development component accounts for only $5 \%$ of the variation. Although $\mathrm{F}$ value is significant at $95 \%$ level, the $t$ value for this component is not significant at $95 \%$ confidence level. The implication of this is that the industrial development component does not provide a significant explanation towards the variation in intra-city trip generated in urban centers of Ogun State.

The concentrated pattern of distribution of industrial establishment in the state (Solanke 2005) may be responsible for this observation.

Based on the above explanation, the regression model for the relationship between mean trip generated by urban centers and socio/commercial components in this study is as follows:

$$
\text { METG }=37.14+4.755 \mathrm{X} \text {; where }
$$

METG = mean trip generated

$$
\mathrm{X}=\text { social/commercial component }
$$

The equation is not due to chance as the F-value is statistically significant at 95\% confidence level. Since the $t$ value of industrial development component is not significant, it is not included in the equation. Intra-city trip generation in the study area is thus, a direct function of the level of social/commercial component. This finding is in agreement with earlier finding of Filani [1972] and Lee [1972] (both in industrialized society) and Oyesiku [1990] (in developing country) that population and other socio-economic factors are important factors, positively predicting trips generated by the urban centers at the intra city level. With the above result, it is plausible to state that just as socio-economic variable are important as predictors of inter-city trip, they are equally important in the prediction of intra-city trips. In other words, the findings of scholars like Filani [1972], Lee [1972], and Oyesiku [1990] on travel behavior at intercity level can be applied to intra-city level by this study.

\section{Conclusion}

The influence of socio-economic variables of urban centers on intra-city travel in Ogun State, Nigeria is examined in this study. There exist a positive interactive pattern between trips generated and socio-eco-

\section{References}

Abumere, S.I. (1987), So the rich areas get even richer, some meditations on the duality in the space-economy of Nigeria, Faculty of social scienceslecture, University of Ibadan.

Ademiluyi, I.A. (1996), An analysis of spatio-temporal pattern of inequalities in Ogun State, Nigeria, Unpublished PhD Thesis, university of Ibadan.

Adeniyi, S.A. (1981), Public transportation and urban Developmet strategy in Nigeria, Unpublished $P h D$ Thesis, University of Wales, Pontain.

Adeniji, K. (1985), Urban transportation system in Nigeria, ODU: A Journal of West African studies 28 : 81-97.

Adeniji, K. (1987), Public transportation and basic nomic variables of urban centers. This shows that these variables constitute potential for spatial interaction in urban centers. There is high positive correlation coefficient $[\mathrm{ryx}>0.7 \mathrm{P} \leq 0.5]$ between trips generated and the following variables primary schools, hotels, population, private health centers, secondary schools, stadium/ sport centers, telephone lines and traditional markets. There is fairly high positive correlation (ryx between 0.5 and 0.6 ), between trips generated and each of postal agencies, public health centers, rate able hereditaments, tertiary institutions, tourist centers and post offices. The strong to fairly high positive correlation between trip generated and most variables other than industrial establishment and modern market shows that these variables are strong potentials and factors of trip generation. The principal component analysis on the socioeconomic variables produced two components, Social/ commercialcomponent and industrial establishment component based on the loadings of variables on them.

The two components accounted for 58.68\% ( $\mathrm{F}=$ $7.830 \mathrm{P} \leq 0.5$ ) of the variation in intra-city trips generated in the state. Social and commercial component explains 58.80\% ( $\mathrm{F}=13.982 \mathrm{P} \leq 0.5)$, while industrial development component does not provide significant explanation towards the variation in intra-city trip generated.

All socio-economic variables used in this study with the exception of industrial development have direct positive influence on intra-urban generated. The finding of this study is important to transport geographers, Hitherto, urban geographers and transport planners in particular, tend to rely heavily on socio-economic characteristics of residents in their explanation of urban travel behavior. However, the positive significant contribution of social and economic variables to trip generation shows that researchers need to be critical in using socio-economic characteristics of residents alone as factors of household travel in developing nations. Furthermore, development of social and economic variables in cities should be regularly monitored and well planned for because of its influence on trip generation.

needs satisfaction in Nigeria, Research for development 4 (1๘2): 292-304.

Akanni, C.O. (2000), Physical environment in Onakomaiya, S.O: Odugbemi, O.O., Oyesiku, O.O and Ademiluyi, I.A (eds) Ogun State: local and regional perspectives, center for sandwischprogrammes (CESAP) Ogun State University, Ago-Iwoye:14 - 26.

Ayeni, M.A.O. (1974), Predictive modeling of urban spatial structure: the example of Jos, Benue-Plateau state; Unpublished PhD Thesis, University of Ibadan.

Ayeni, B. (1979), Concepts and Techniques in urban analysis, Croom Helm Ltd, London.

Ayeni, B. (1974), Quantitative methods for Geography students, Research support services, Ibadan. 
Barber, G. (1995), Aggregate characteristics in urban travel' in Hanson, S. (ed) The geography of urban transportation 2 nd edition, the Guilford Press, New York.

Blalock, H.M (1963), Correlated independent variables, The problems of multi Collinearity Social Forces 42: 233-237.

Cattel, R.B. (1966), The scree test for number of factors, Multivariate behavioral research 1: 245 - 276.

Dimitriou, H.T. (1995), A Developmental Approach to urban transport planning: an Indonesian illustration, Avebury, Ashgate publishing limited.

Filani, M.O. (1972), Changing pattern of central places and functional regions: temporal and spatial dynamics of air traffic flows in the United States, Unpublished PhD Thesis, Penn State university.

Ghaffar, F.A. (1987), Regional inequalities and Development in Peninsular Malaysia, Malaysian journal of tropical geography 16: 21 - 36.

Hanson, S., and Schwab, M. (1995), Describing disaggregate flows: individual and household activity patterns' in Hanson, S (ed) The geography of urban transportation, 2nd ed., The Guilford Press, New York.

Hauser D.P (1974), Some Problems in The Use of StepWise Regression Techniques in GeographicalResearch, Canadian Geographer XVIII: 148 - 158.

Kaiser, H.P. (1960), The application of electronic components to factor analysis, Educational and psychological measurement 20: 141 - 151.

Lee, D.T. (1972), Development of a mathematical model and information system for forecasting intercity trip demands for the Taipei Taiwan Metropolitan area, Unpublished PhD Thesis, Michigan State university.

Odugbemi, O.O. (1993), Ogun State' in Udo, R.K. and Mamman D (eds) Nigeria: Giant in the tropics, Gabumo Press Lagos.

Odugbemi, O.O., \& Solanke, M.O. (1997), The geographical region, setting, structure and impact of the Ogun State University in Odugbemi, O.O., Balogun, K.A.; Adebanjo A, and Adedoyin, S.F. (ed)
Essential of general studies, Vol 1; center for sandwich programmers (CESAP) Ogun State University, Ago-Iwoye.

Ogunjumo, A. (1986), The pattern of trip generation at Ile-Ife, Journal of Nigeria Institute of town planners VI\&VII: 99 - 144.

Ogunsanya A.A. (2002), Maker and Breaker of cities' The 59th Inaugural lecture, University of Ilorin, Ilorin.

Ogunsanya, A.A., \&Vandu-Chikolo I. (2004), Conclusion where do we go from here?In VanduChikoluOgunsanya, A.A. and Sunmaila, A.G. (eds) Perspective on urban transportation in Nigeria, NITT, Zaira.

Ojo, O.E (1990), Urban travels-activity patterns: A case study of Ibadan, Nigeria, Unpublished PhD Thesis, university of Ibadan.

Okoko, E. (2000), Quantitative techniques in urban analysis, Kraft Books Limited.

Onyemelukwe, J.O.C. (1981), Socio-economic indicators of development in Nigeria, Monograph Series, No. 1, Department of Geography, University of Ibadan.

Oyebanji, O.J. (1981), Regional inequalities in Economics Growth and Developmen: A case study from Nigeria, Journal of the Nigeria institute of town planners 1(1): $71-85$.

Oyesiku, O.O. (1990), Inter-urban travels pattern in $\mathrm{Ni}$ geria: A case study of Ogun state, Unpublished $\mathrm{PhD}$ Thesis, University of Benin.

Oyesiku, O.O. (2010), New cities in urban and regional development planning, Longman, Ikeja.

Raji, B.A (2013), Spatial analysis of pedestrian traffic in Ikeja, Lagos State, Nigeria, Unpublished PhD Thesis, University of Ibadan.

Solanke, M.O. (2005), Spatial analysis of intra-urban travel pattern in Ogun State, Unpublished PhD thesis, University of Ibadan.

Vandu-Chikolo I, (2004), Urban transport infrastructure, in Vandu-CHikolo, I. Ogunsanya, A.A. and Sumaila, A.G (eds) Perpectives on urban transportation in Nigeria, NITT, Zaira. 